\title{
Drie mogelijke verklaringen voor de stagnerende ontwikkeling van het Nederlandse bioscoopbedrijf in de jaren dertig
}

\section{Inleiding}

Het Nederlandse bioscooppark was in de jaren dertig beduidend kleiner in omvang dan dat van andere westerse landen. Was er in Nederland één bioscoopstoel per 48 inwoners, in België was dit één per zestien inwoners en in Groot-Brittannië was deze verhouding één op twaalf. ${ }^{I}$ Dit is geen nieuwe constatering en recent droegen Karel Dibbets (2006), en Judith Thissen en André van der Velden (2009) in dit tijdschrift verklaringen aan voor deze achterblijvende belangstelling voor de film. ${ }^{2}$

Karel Dibbets poneert in zijn artikel 'Het taboe van de Nederlandse filmcultuur' de stelling dat als de zuilen de bioscopen meer hadden omarmd er een beter ontwikkelde bioscoopcultuur was geweest in Nederland. ${ }^{3}$ In plaats van het aanbieden van verzuild vermaak werd echter door de exploitanten gestreefd naar een zo neu-

* Clara Pafort-Overduin is docent bij de opleiding Theater-, film- en televisiewetenschap van de Universiteit Utrecht. Zij schrijft haar proefschrift over de Jordaanfilms in de jaren dertig en de wijze waarop die een idee van nationale identiteit opriepen en uitdrukten, in het kader van het door NWo gefinancierde project Cinema, modernity and cultural identity in the Netherlands, 1895-1940. Daarnaast werkte ze samen met Douglas Gomery aan een herziene editie van Movie History: A Survey dat in april 20II zal verschijnen bij Routledge. E-mail: C.Pafort-Overduin@uu.nl.

John Sedgwick is professor Film Economics en tevens hoofd van het Centre for International Business and Sustainability van de London Metropolitan University. Hij is de auteur van onder andere Popular Filmgoing in 1930 B Britain. A choice of pleasures, Exeter, Exeter University Press (2000) en coeditor met Mike Pokorny van An Economic History of Film, London, Routledge (2005). Zijn publicaties over de economische geschiedenis van film verschenen onder andere in Economic History Review, Journal of Economic History, Explorations in Economic History, en Journal of Cultural Economics. Momenteel werkt hij aan twee projecten over filmconsumptie en -distributie in Sidney en Philadelphia. E-mail: J.Segdwick@londonmet.ac.uk.

Jaap Boter studeerde muziekwetenschap en promoveerde in de economie op het analyseren van grote transactiedatasets van culturele instellingen (box office-data, uitleengegevens bibliotheken, gebruik Museumjaarkaart, etc.). Sinds 200I is hij verbonden aan de Faculteit Economische Wetenschappen en Bedrijfskunde van de Vrije Universiteit Amsterdam en is hij zich met name gaan specialiseren in het gebruik van digitale kaarten en GIS (Geografisch informatie systeem) software voor het analyseren van ruimtelijke patronen in dergelijke culturele datasets. Tevens is hij sinds 2009 bijzonder hoogleraar Boekhandel aan de Universiteit van Amsterdam. E-mail: jboter@feweb.vu.nl. 
traal mogelijke sfeer in de bioscopen. ${ }^{4}$ Dibbets stelt verder dat niet de religieuze oriëntatie van Nederland het bioscooplandschap heeft bepaald, maar een combinatie van beperkende censuurvoorschriften, hoge belastingen en kartelvorming. Zo werden volgens Dibbets de hoge vermakelijkheidsbelastingen die de stadsbesturen oplegden door de bioscoopbond bestreden met kartelvorming, prijsafspraken en beperking van het aantal bioscopen. Hierdoor kon men weliswaar minder publiek herbergen maar bleven wel de inkomsten van de bioscoophouders op pij1.5 Prijsafspraken betekenen hoge prijzen die op hun beurt een remmende werking kunnen hebben op de verkoop. In dit artikel onderzoeken we dit effect.

Thissen en Van der Velden reageerden in hun artikel 'Klasse als factor in de Nederlandse filmgeschiedenis' op Dibbets. Zij menen dat de aandacht voor de verzuiling een blinde vlek heeft opgeleverd waardoor het begrip klasse over het hoofd is gezien. Op basis van onderzoek in Rotterdam betogen zij dat de 'acceptatie van de bioscoop als legitiem amusement voor het burgerlijk publiek op zijn minst tot de jaren dertig zeer beperkt is gebleven. Als gevolg hiervan bleef de bioscoop in ons land sterker dan elders het domein van de lagere klassen en standen en daarmee in potentie een alternatieve publiekssfeer' ${ }^{6}$ De auteurs constateren in Rotterdam een bouwgolf tussen I9I6 en I922 die een tiental bioscooptheaters opleverde met tussen de 1000 en 1600 zitplaatsen.7 Ze betogen dat deze zogenaamde picture palaces in Nederland niet - zoals wordt verondersteld voor hun Amerikaanse evenknie bedoeld waren om een gevestigd middenklassenpubliek aan te trekken maar juist om 'te kunnen voldoen aan een sterk toegenomen vraag naar bioscoopvertier vanuit sociaal-cultureel lager gesitueerde groepen'. 8 Thissen en Van der Velden zoeken dus de verklaring voor de achtergebleven ontwikkeling van het Nederlandse bioscooplandschap in elk geval tot het eind van de jaren twintig, in de samenstelling van het bioscooppubliek dat vooral zou bestaan uit de lagere arbeidersklasse. In dit artikel zullen we een eerste poging doen de verklaringen die Dibbets en Thissen en Van der Velden aanvoeren te toetsen. Alvorens de effecten van prijs, kartelvorming, religie en klasse te onderzoeken, karakteriseren we de Nederlandse bioscoopmarkt door die in een internationaal vergelijkend perspectief te plaatsen. In hoeverre weken de Nederlandse distributie- en vertoningpatronen af van die in de Angelsaksische wereld?

\section{Het Angelsaksische model van distributie en vertoning}

In Amerika en Engeland werd eind jaren tien en begin jaren twintig van de vorige eeuw een filmdistributiemodel ontwikkeld dat was gebaseerd op de voorkeuren van het publiek, die duidelijk werden door de kaartverkoop. De vraag van het publiek bepaalde de toevoer: was deze groot dan bracht men meer kopieën uit. Om de beslissing te kunnen nemen of er al dan niet extra kopieën nodig waren, werd een logistiek model ontwikkeld dat de informatiestroom tussen distributeur en vertoner regelde. Dure producties werden eerst uitgebracht in een klein aantal grote 
premièrebioscopen in metropolen waar ze naamsbekendheid genereerden en draaiden zolang ze voldoende opbrachten. Daarna verplaatsten de films zich volgens een cascademodel naar een reeks van groot naar klein aflopende andere bioscopen. Elke fase in dit proces werd als een aparte run beschouwd en tussen deze runs was er een periode dat de film niet vertoond werd. Toeschouwers kozen er dus voor om een film op een bepaald moment in deze reeks te bezoeken. Wilde men als eerste een nieuwe film zien dan moest er meer betaald worden dan wanneer men wachtte tot een film in een kleiner, vaak minder goed uitgerust theater was aanbeland. Bovendien was de kopie dan meestal in een slechtere staat.

Anders dan tegenwoordig had het publiek in de jaren dertig alleen door naar de bioscoop te gaan toegang tot een film. Dat beperkte de commerciële looptijd van een film tot maximaal vijftien maanden. ${ }^{9} \mathrm{Na}$ deze periode verdween een film van de markt en was hij in principe niet meer voor de toeschouwer beschikbaar. Door dit distributiesysteem ontwikkelde zich wellicht voor de eerst keer in de geschiedenis een markt waarin de opbrengsten waren verdeeld volgens het long tail-model. Slechts een klein aantal films genereerde heel veel opbrengsten en heel veel films genereerden weinig opbrengsten. ${ }^{10}$

Het hiervoor beschreven patroon van een long tail vinden we halverwege de jaren dertig bijvoorbeeld terug in de middelgrote Engelse provinciesteden Bolton, met I80.000 inwoners en I8 bioscopen, Brighton met goed 200.000 inwoners en I8 bioscopen, en Portsmouth met 250.000 inwoners en 2I bioscopen. Deze drie plaatsen kunnen beschouwd worden als representatief voor de stedelijke filmdistributie in de Angelsaksische landen. ${ }^{\text {II }}$ Met een periode van drie weken tussen de verschillende runs is het distributiepatroon in de drie provinciesteden een miniatuuruitgave van het eerder beschreven model dat gehanteerd werd voor de grote steden in de Verenigde Staten, met als belangrijkste verschil dat verlengde looptijden (dus langer dan één week) in lokale premièrebioscopen zeldzaam waren. Tabel I toont het verspreidingspatroon in elk van de drie plaatsen: Portsmouth voor het kalenderjaar I934, Bolton en Brighton voor de jaren I934-I935. De long tail is duidelijk zichtbaar in het distributiepatroon in deze drie steden: de waarschijnlijkheid dat een film een extra boeking krijgt, neemt exponentieel af met elke extra boeking die een film heeft gekregen. Veel films haalden niet meer dan een enkele boeking en kenden dus weinig opbrengsten; slechts enkele films haalden veel boekingen en kenden dus veel opbrengsten.

In de Angelsaksische landen werd een model van filmdistributie ontwikkeld dat sterk overeen kwam met een prijsdiscriminatiemodel. ${ }^{22}$ Distributeurs waren gericht op winstmaximalisatie en bespaarden tegelijkertijd kosten door zo min mogelijk filmkopieën in omloop te brengen. Op die manier probeerden ze het verspreidingspatroon van een film in tijd en ruimte te controleren. ${ }^{\mathrm{I}}$ De populairste films in bijvoorbeeld Groot-Brittannië hadden niet alleen verlengde looptijden in de grote bioscopen op Londens West End en provinciale stadscentra, maar hadden ook verschillende runs in de theaters in Bolton, Brighton, Portsmouth en werden daarnaast 
TABEL 1. Het distributiepatroon van films die zijn uitgebracht in Portsmouth (1934), Bolton (1934-1935) en Brighton (1934-1935)

\begin{tabular}{|c|c|c|c|c|c|c|}
\hline \multirow[b]{2}{*}{ Boekingen } & \multicolumn{2}{|c|}{$\begin{array}{l}\text { Portsmouth } \\
\text { (Inwoners 250.000) }\end{array}$} & \multicolumn{2}{|c|}{$\begin{array}{l}\text { Bolton } \\
\text { (Inwoners I80.000) }\end{array}$} & \multicolumn{2}{|c|}{$\begin{array}{l}\text { Brighton } \\
\text { (Inwoners 202.42I) }\end{array}$} \\
\hline & $\begin{array}{l}\text { Aantal films } \\
\text { met } \\
n \text {-boekingen }\end{array}$ & $\begin{array}{l}\text { Relatieve fre- } \\
\text { quentie van } \\
\text { films met } n \text { - } \\
\text { boekingen }\end{array}$ & $\begin{array}{l}\text { Aantal films } \\
\text { met } n \text {-boekin- } \\
\text { gen }\end{array}$ & $\begin{array}{l}\text { Relatieve fre- } \\
\text { quentie van } \\
\text { films met } \\
n \text {-boekingen }\end{array}$ & $\begin{array}{l}\text { Aantal films } \\
\text { met } \\
n \text {-boekingen }\end{array}$ & $\begin{array}{l}\text { Relatieve fre- } \\
\text { quentie van } \\
\text { films met } \\
n \text {-boekingen }\end{array}$ \\
\hline I & 573 & I & I3O4 & I & I474 & I \\
\hline 2 & 504 & 0.880 & 964 & 0.739 & II4O & 0.773 \\
\hline 3 & 407 & 0.710 & 684 & 0.525 & 860 & 0.583 \\
\hline 4 & 297 & 0.518 & $4 \mathrm{II}$ & 0.315 & 522 & 0.354 \\
\hline 5 & 199 & 0.347 & $2 \mathrm{I} 4$ & $0.16_{4}$ & 265 & 0.180 \\
\hline 6 & II2 & 0.195 & I07 & 0.082 & 96 & 0.065 \\
\hline 7 & 55 & 0.096 & 43 & 0.033 & $4 \mathrm{I}$ & 0.028 \\
\hline 8 & $2 \mathrm{I}$ & 0.037 & 16 & 0.012 & $\mathrm{I} 4$ & 0.009 \\
\hline 9 & 4 & 0.007 & 3 & 0.002 & 3 & 0.002 \\
\hline IO & 0 & 0 & I & 0.000 & 0 & 0 \\
\hline
\end{tabular}

Bron: Sedgwick, Popular Filmgoing in 1930 s Britain; Sedgwick, 'Cinemagoing in Portsmouth during the I930s'. Toelichting: Elke vertoonde film moet in elk geval eenmaal geboekt zijn. Dus in I934 werden 573 films vertoond in Portsmouth, in I934-I935 (twee jaar) in Bolton I304 films en in Brighton I474 films. De relatieve frequentie wordt uitgedrukt als het aantal films dat ten minste een bepaald aantal boekingen kreeg ten opzichte van het totaal aantal films dat ten minste eenmaal geboekt werd.

breed verspreid vertoond op andere plaatsen in het land. Films konden dus op verschillende momenten van hun levenscyclus 'geconsumeerd' worden en het publiek dat aan het eind van de curve naar de film ging, betaalde een aanzienlijk lager bedrag voor dezelfde film dan degenen die naar de premièrebioscopen in de stadscentra gingen. ${ }^{\mathrm{I}}$

\section{Het Nederlandse distributie- en vertoningsmodel}

Om de Nederlandse vertonings- en distributiepraktijk te reconstrueren, is er een dataset gecreëerd waarin de geadverteerde filmprogramma's van 145 bioscopen in 22 plaatsen in Nederland in de periode 1934-I936 zijn opgenomen. ${ }^{15}$ Deze dataset dekt iets meer dan veertig procent van het totale aantal theaters dat door het Centraal Bureau voor de Statistiek werd geteld in $1937 \cdot{ }^{16}$ In de dataset zijn alle films (en hun productiegegevens) opgenomen die ten minste eenmaal geadverteerd werden door een van de bioscopen uit de verzameling. Voor zover ons bekend is dit de meest uitgebreide dataset van bioscoopbezoek van een land uit die periode, zowel wat betreft het scala van vertoonde films als de omvang van het stedelijke gebied dat gedekt wordt en reikt van Amsterdam met een bevolking van 78I.645 tot Zierikzee 
dat slechts 6944 inwoners telde in deze periode. Voor I4 van de 22 plaatsen is de informatie afkomstig uit de lokale kranten waarin de bioscopen adverteerden: Alkmaar, Apeldoorn, Culemborg, Dordrecht, Eindhoven, Haarlem, 's-Hertogenbosch, Leiden, Nijmegen, Schiedam, Tiel, Tilburg, Utrecht en Zeist. Voor de overige acht steden leverde de Cinema Context-website de informatie voor de wekelijkse vertoningen: Amsterdam, Rotterdam, Den Haag, Groningen, Maastricht, Heerlen, Geleen en Zierikzee. De Cinema Context-data werden aangevuld met het aantal voorstellingen dat een film per week draaide zoals dat ook voor de overige veertien steden was gedaan. ${ }^{\mathrm{I7}}$ In totaal bevat de dataset de gegevens van $24 \mathrm{II}$ feature films die gezamenlijk 26.059 vertoningen beslaan. Er zijn I3.I34 single bill-programma's geregistreerd en $6_{5} 67$ double bill-programma's. Elk programma draaide normaal gesproken een week maar het aantal voorstellingen per week kon verschillen. ${ }^{\text {I8 }}$

Zoals blijkt uit tabel 2 komt het distributiepatroon van de drie grootste Nederlandse steden Amsterdam, Rotterdam en Den Haag het meest overeen met dat van Bolton, Brighton en Portsmouth. Hoewel deze drie Nederlandse steden twee tot vier keer zoveel inwoners hadden als de drie Engelse, werden er minder films per jaar vertoond. Dit geeft aan dat er minder doeken beschikbaar waren. Bovendien waren er minder films die een extra boeking hadden in andere theaters, hetgeen erop duidt dat de films eerder van de markt verdwenen waren en een minder wijdvertakt distributiepatroon volgden. ${ }^{\mathrm{I} 9}$ Buiten deze grote steden was de omloopsnelheid nog hoger, wat niet verrassend is omdat de mogelijkheden om films in meerdere programma's te vertonen afnemen naarmate het aantal inwoners daalt.

Opvallend in tabel 2 is de ongelijkheid tussen het aantal van de 24II films dat ten minste eenmaal vertoond is op de nationale markt en het aantal films dat vertoond is in de drie grote steden Amsterdam, Rotterdam en Den Haag waar respectievelijk Io68, 875 en 890 minder films vertoond werden. Met andere woorden een groot deel van de 24II films volgde niet het hiërarchische distributiepatroon waarbij de films zich verplaatsen van grote naar kleinere plaatsen respectievelijk bioscopen maar belandde direct in de provincieplaatsen. Zeker in vergelijking tot de Britse en Amerikaanse first-run-markten waar het commerciële leven van een film ongeveer vijftien maanden was, was er op de Nederlandse filmmarkt een groot aantal (oude) films in circulatie die incidenteel nog werden vertoond. Om het gedrag van de films op de Nederlandse markt te visualiseren is per vijf films het voortschrijdend gemiddelde berekend van het aantal plaatsen waar deze films vertoond werden. 


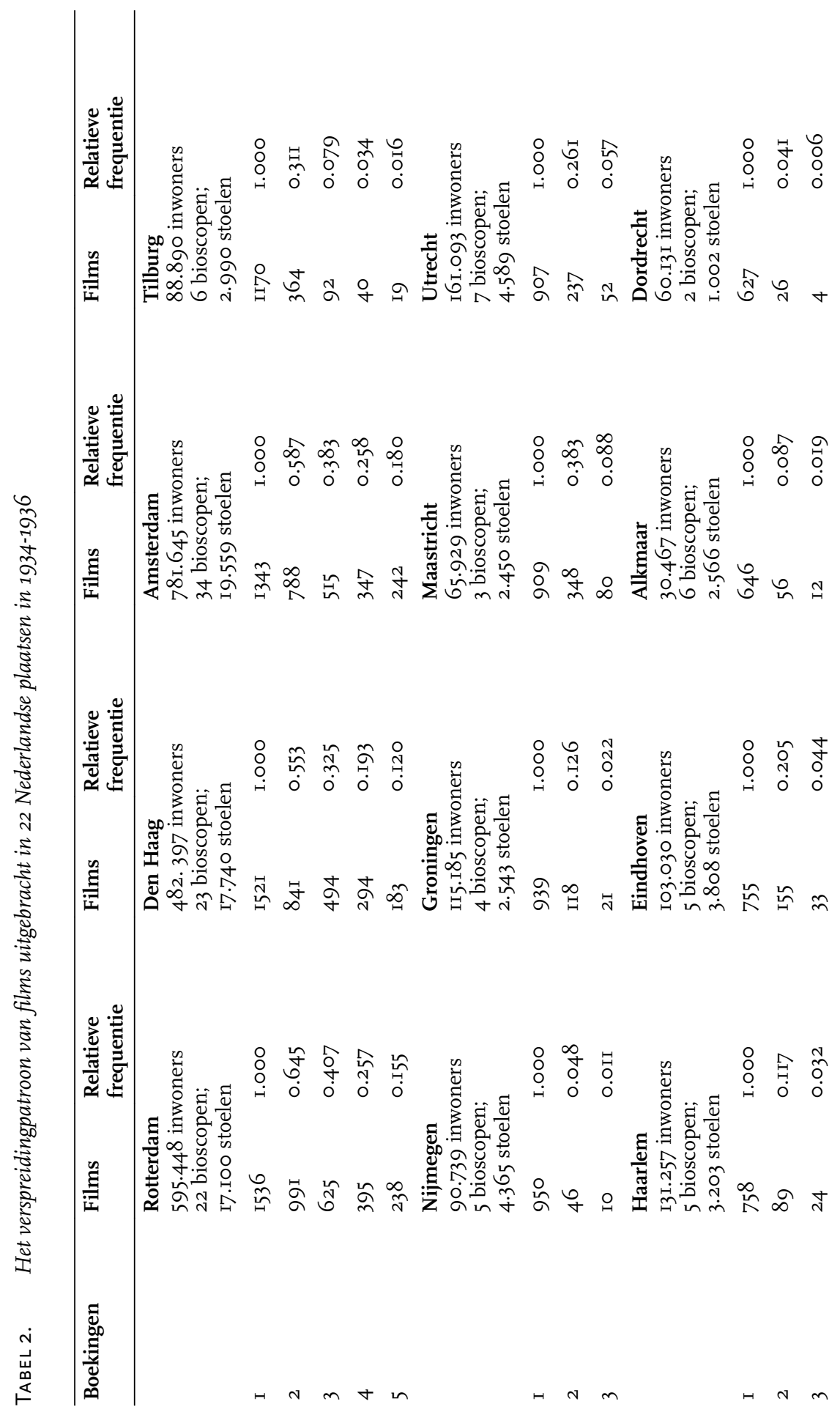




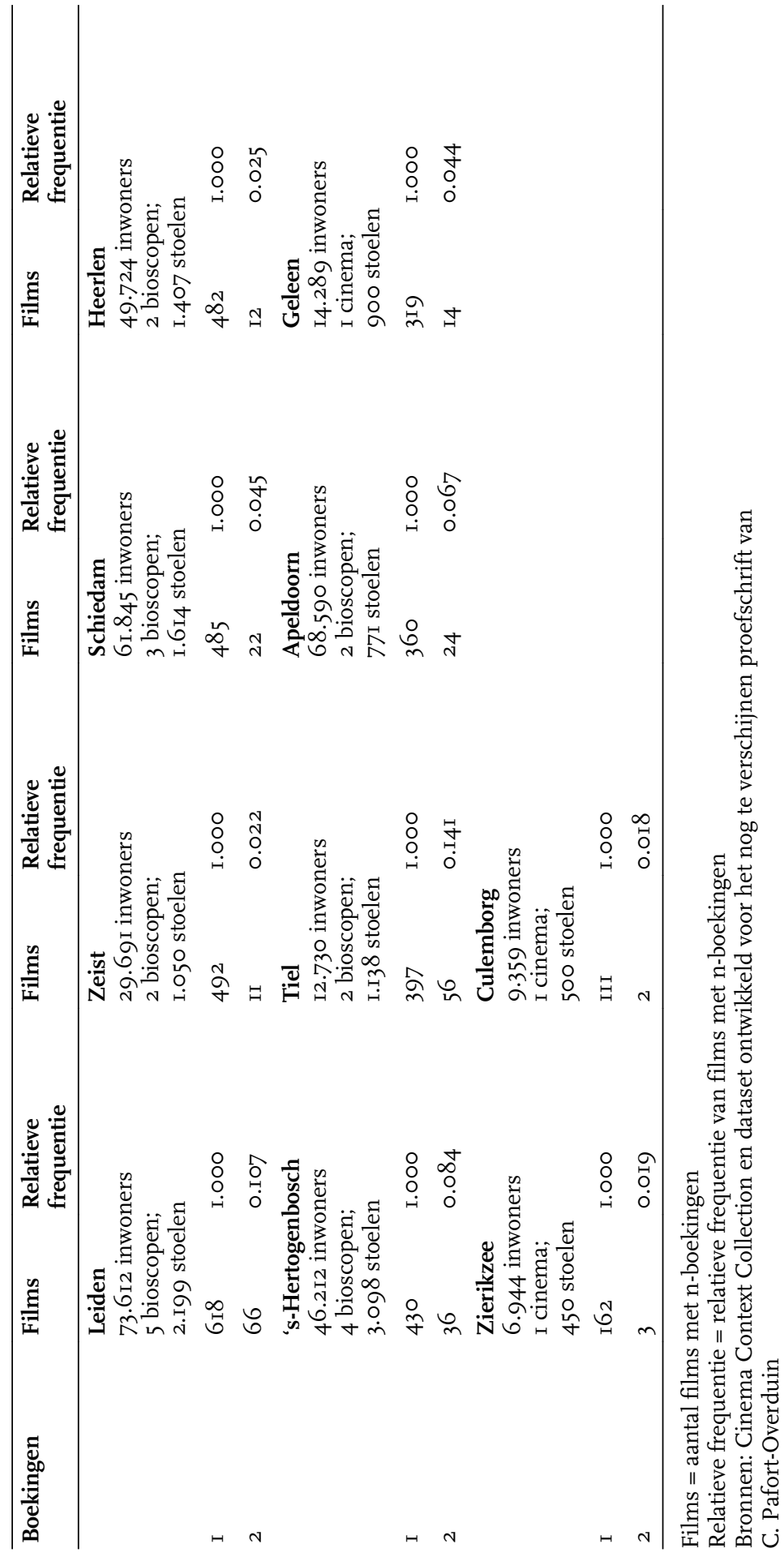


Het per vijf films voortschrijdend gemiddelde in figuur I laat zien dat ongeveer de helft van de 24II films in roulatie draaide in slechts vijf of minder van de 22 plaatsen in de dataset, waarbij ze meestal zelfs slechts in één bioscoop in die plaatsen vertoond werden. ${ }^{20}$ De Britse en Amerikaanse datasets waar we eerder aan refereerden, kennen dit soort 'incidentele' films niet. Dit lijkt te duiden op een relatieve onderontwikkeling van bepaalde delen van de Nederlandse markt. Deze films hadden immers maar een zeer beperkte distributie. ${ }^{2 \mathrm{I}}$ Daartegenover staan de vijfhonderd populairste films in Nederland, die in ten minste de helft van de plaatsen uit de steekproef draaiden, waarbij de top 20 bijna overal vertoond werd. Dit betekent dat ook de kleine plaatsen uit de steekproef bereikt werden; de Nederlandse distributie kon dus wel ver reiken. De grootste kaskraker van de periode I934-I936, DE JANTJES, werd vertoond in alle plaatsen uit de dataset en kwam in 49 van de I45 bioscopen. Zoals ook het geval was in Bolton, Brighton en Portsmouth, draaiden de populairste films in Nederland in de belangrijkste bevolkingsgebieden. Meer dan vierhonderd van de top 500-films werden in acht steden vertoond: Amsterdam (497), Rotterdam (49I), Den Haag (488), Utrecht (435), Groningen (4I9), Tilburg (4I2), Maastricht (408) en Nijmegen (402). Alle top 200-films werden vertoond in Amsterdam en Rotterdam. Van de overige steden vertoonde Maastricht met een bevolking van iets meer dan 66.000 zielen de minste films uit de top 200categorie, namelijk slechts I75.

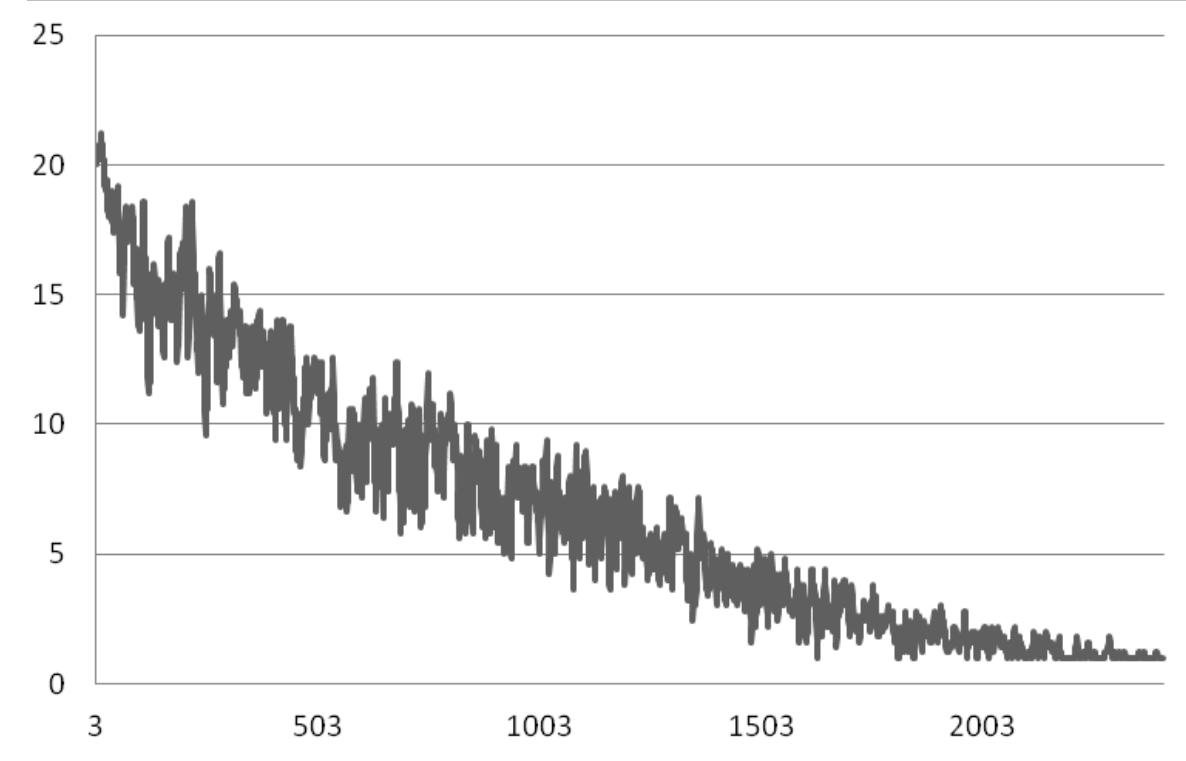

FIGUUR 1. Per vijf films voortschrijdend gemiddelde van films die vertoond zijn in Nederlandse plaatsen in de periode 1934-1936 $x$-as: Films in volgorde van populariteit, van hoog naar laag. $\gamma$-as: Aantal plaatsen waarin de films zijn vertoond 
De cijfers van het bioscoopbezoek die we hier presenteren zijn in vele opzichten verrassend daar men zou verwachten dat de relatief lage bioscoopcapaciteit in Nederland zou hebben geleid tot een beperkte verspreiding van films en dus een plattere trend in figuur I. De films werden wijd verspreid en de meest populaire films werden bovendien meerdere malen geboekt in de grote steden. De Nederlandse filmmarkt lijkt dus een microkosmos van het Angelsaksische model, maar was kleiner in schaal en minder intens zoals blijkt uit de lage snelheid waarmee de films circuleerden. De conclusie is dus gerechtvaardigd dat er ondanks het verschil met het Angelsaksische distributiepatroon (de aanwezigheid van veel oude films die incidenteel vertoond werden) niets intrinsiek anders was aan het Nederlandse distributiemodel dat de genoemde ongelijkheid in zitplaatsen en bezoeken zou verklaren.

\section{Vergelijkende statistieken: hoe ver bleef de Nederlandse filmmarkt achter?}

Het Centraal Bureau voor de Statistiek telde in 1937 in Nederland 333 bioscopen met een totale capaciteit aan zitplaatsen van I74.I45. Ook als men corrigeert voor de verschillen in de bevolkingsomvang zijn deze cijfers zeer laag vergeleken bij de berekening van de Britse statisticus Rowson uit I934 die in Groot-Brittannië 4305 bioscopen en 3.872 .000 stoelen telde. ${ }^{22}$ Rowson schatte dat er net onder een miljard bioscoopbezoeken per jaar werden gebracht in Groot-Brittannië, een aantal dat door Browning en Sorrell licht werd bijgesteld naar 9ro miljoen. ${ }^{23}$

TABEL 3. Vergelijkende cijfers van jaarlijkse gemiddelden, 1934-1936

\begin{tabular}{|c|c|c|c|c|c|c|c|c|c|}
\hline & $\begin{array}{l}\text { Inwo- } \\
\text { ners } \\
\text { (x IO০০) } \\
\text { (I) }\end{array}$ & $\begin{array}{l}\text { GDP per } \\
\text { hoofd v/ } \\
\text { d bevol- } \\
\text { king } \\
\text { (\$ US) } \\
(2)\end{array}$ & $\begin{array}{l}\text { Aantal } \\
\text { verkochte } \\
\text { toegangs- } \\
\text { bewijzen } \\
\text { (miljoe- } \\
\text { nen) } \\
(3)\end{array}$ & $\begin{array}{l}\text { Jaarlijks } \\
\text { aantal } \\
\text { toegangs- } \\
\text { bewijzen } \\
\text { per hfd v/ } \\
\text { d bevol- } \\
\text { king (4) }\end{array}$ & $\begin{array}{l}\text { Aantal } \\
\text { biosco- } \\
\text { pen } \\
\text { (5) }\end{array}$ & $\begin{array}{l}\text { Bioscoop- } \\
\text { stoelen } \\
(6)\end{array}$ & $\begin{array}{l}\text { Stoelen } \\
\text { per } \\
\text { bioscoop } \\
\text { (7) }\end{array}$ & $\begin{array}{l}\text { Inwoners } \\
\text { per } \\
\text { bioscoop } \\
\text { (8) }\end{array}$ & $\begin{array}{l}\text { Inwoners } \\
\text { per } \\
\text { bioscoop- } \\
\text { stoel } \\
\text { (9) }\end{array}$ \\
\hline $\begin{array}{l}\text { Neder- } \\
\text { land }\end{array}$ & 8.430 & $4 \cdot 975$ & 33 & 4 & 333 & I74.I45 & 523 & $25 \cdot 3 \mathrm{I} 5$ & $48,4 \mathrm{I}$ \\
\hline $\begin{array}{l}\text { Groot- } \\
\text { Brittan- } \\
\text { nië }\end{array}$ & 46.872 & $5.8 \mathrm{I} 4$ & 910 & I9 & $4 \cdot 305$ & 3.872 .000 & 899 & I0. 888 & $\mathrm{I} 2, \mathrm{II}$ \\
\hline
\end{tabular}

Bronnen: H. Browning \& A. Sorrell, 'Cinema and cinema-going in Great Britain' (I954); Centraal Bureau voor de Statistiek, Statistiek van het bioscoopwezen 1937; K. Dibbets \& F. Van der Maden (red.), Geschiedenis van de Nederlandse film en bioscoop tot 1940 (I986); Film Daily Yearbook (1938); A. Maddison, The World Economy; A Millennial Perspective (Paris, 200I); S. Rowson, 'A Statistical Survey of the Cinema Industry in Great Britain in I934’ (I936); J. Sedgwick, Popular Filmgoing in 1930s Britain (2000).

Toelichting: De Britse en Nederlandse cijfers zijn gemiddeld voor I934-I936.

Tabel 3 toont dat het aantal inwoners per bioscoop (kolom 8) in Nederland tweeënhalf keer dat van Groot-Brittannië was. Dit verschil loopt op tot viermaal wanneer 
men het aantal bioscoopstoelen (kolom 9) vergelijkt. De Britten gingen zelfs vijfmaal vaker naar de bioscoop dan de Nederlanders. Deze grote verschillen representeren investeringsbeslissingen in de bouw van bioscopen. Met andere woorden: in Nederland besloten ondernemers minder vaak om (grote) bioscopen te bouwen. Gegeven het feit dat de formele, institutionele regelingen en het inkomensniveau per hoofd van de bevolking vergelijkbaar waren in de twee landen, moeten deze verschillen verklaard worden door - in economische termen gesteld - ofwel een zwakke vraag die bijvoorbeeld veroorzaakt werd door een sociale norm die bioscoopbezoek afkeurde, ofwel een beperkt aanbod, of een combinatie van die twee.

In tabel 4 vergelijken we de macro-economische omstandigheden van het bioscoopbezoek in Groot-Brittannië en Nederland. De schatting van het aandeel van het bioscoopbezoek in de Nederlandse consumptie-uitgaven is gebaseerd op een telling van het aantal kaartjes dat werd verkocht, de opbrengst van de kaartverkoop en de gemiddelde toegangsprijs in de drie grootste steden (Amsterdam, Rotterdam en Den Haag) voor de jaren 1930-1936. Deze data werden gepubliceerd in het Film Daily Yearbook van 1938 maar komen overeen (en zijn dus waarschijnlijk afkomstig uit) het rapport van het CBS over 1936. Ook Dibbets (1986) gebruikt deze cijfers voor zowel Amsterdam als heel Nederland. ${ }^{24}$ De 1.859 .490 inwoners van de drie genoemde steden beslaan net iets minder dan een kwart van het totaal aantal inwoners van het hele land en dus zijn de cijfers die hieruit afgeleid zijn niet representatief voor het gehele land. Zo gaat volgens tabel 3 de gemiddelde Nederlander viermaal per jaar naar de bioscoop, maar laat tabel 4 zien dat het aantal toegangskaartjes dat per inwoner van de drie grootste steden werd gekocht ruim tweemaal zoveel was in de periode 1934 -1936.

De macro-economische omstandigheden van de twee economieën verschilden aanmerkelijk in de jaren dertig. De nominale uitgaven aan consumptiegoederen daalde in Nederland vanaf 1930 in zes opeenvolgende jaren. Door het aanhouden van de Gouden Standaard steeg bovendien de werkeloosheid jaarlijks, met het hoogtepunt in 1936 toen II,9 procent van de beroepsbevolking werkeloos was. ${ }^{25}$ In Groot-Brittannië was de periode van terugval in consumptieve uitgaven en de stijging van de werkeloosheid veel korter en werd reeds vanaf 1932 het herstel weer ingezet. Concreet was de uitgave aan consumptiegoederen per hoofd van de bevolking in Nederland in 1936 slechts 90 procent van het niveau van I930, terwijl dit in Groot-Brittannië III procent bedroeg. De Nederlandse consumptieve uitgaven die in I930 nog 86 procent van het Britse niveau bedroegen, waren dus in 1936 gedaald naar 70 procent. ${ }^{26}$ 


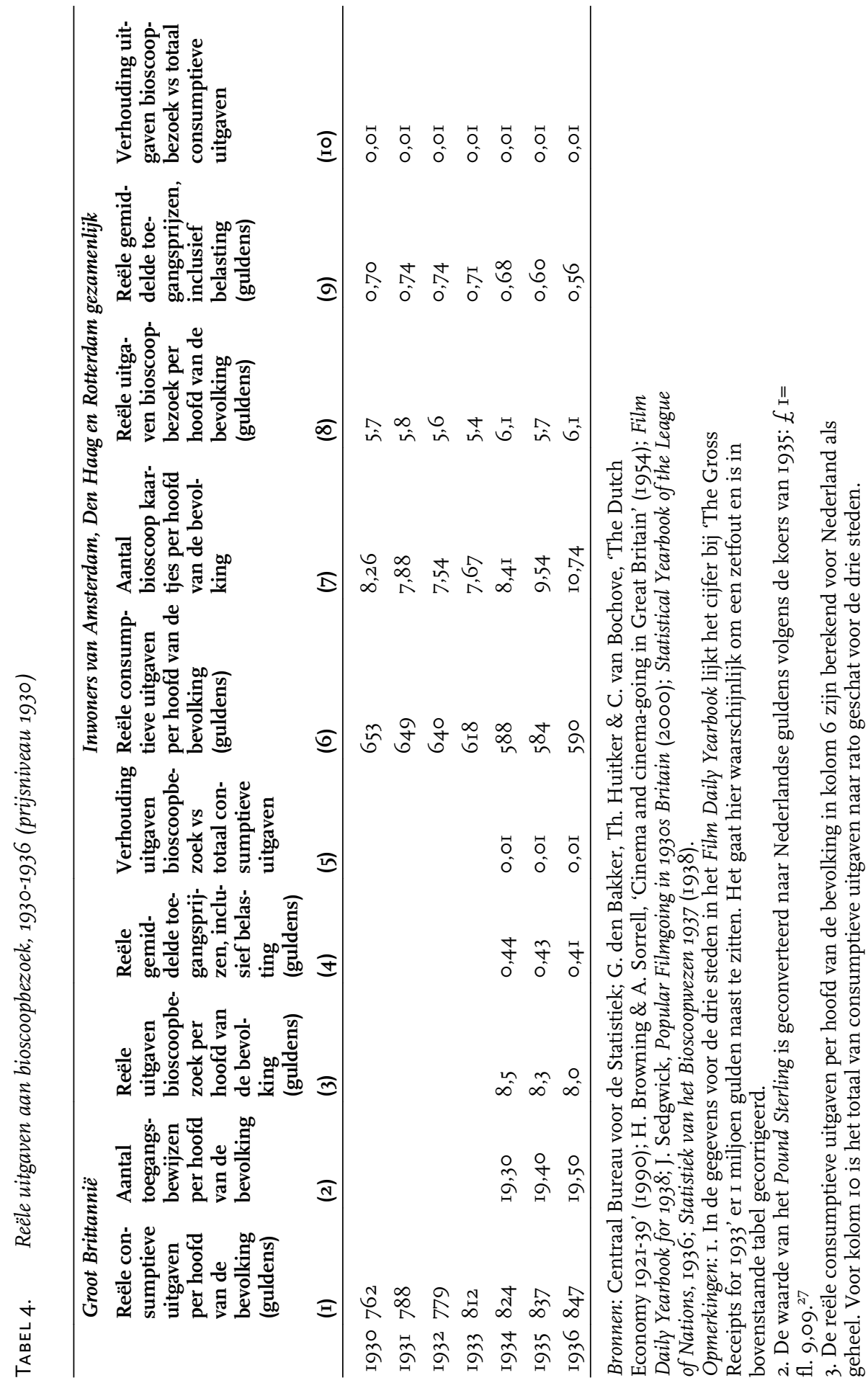


Wat tevens blijkt uit tabel 4 is dat zowel de bevolking van Amsterdam, Rotterdam en Den Haag als de totale Britse populatie ongeveer één procent van haar totale consumptieve uitgaven besteedde aan bioscoopbezoek. In Nederland komt de teruglopende bioscoopkaartjesverkoop overeen met de algemene terugval in consumptieve uitgaven vanaf I930, maar dit effect werd versterkt doordat de nominale toegangsprijzen niet waren meegegaan in de algemene prijsdaling. Hierdoor waren de prijzen van de bioscoopkaartjes in feite gestegen tijdens de eerste jaren van de depressie.

Tabel 4 laat zien dat de Nederlandse toegangsprijzen veel hoger lagen dan in Groot-Brittannië. Aan het begin van de periode 1934-1936 betaalde het Nederlandse publiek ongeveer 50 procent meer dan Britse bioscoopbezoekers. Aan het einde van deze periode is er echter sprake van een dramatische daling van de toegangsprijzen voor de Nederlandse bioscopen. We zullen hier later op terugkomen. Hoewel de Britse consumenten hetzelfde deel van hun uitgaven aan bioscoopbezoek besteedden als hun Nederlandse tegenhangers in Amsterdam, Rotterdam en Den Haag, suggereert tabel 4 dat zij veel vaker naar de film gingen omdat bioscoopkaartjes in Groot-Brittannië veel goedkoper waren. Als de Nederlandse prijzen vergelijkbaar waren geweest met de Britse prijzen dan was het aantal verkochte bioscoopkaartjes per hoofd van de bevolking mogelijk bijna tweemaal zoveel geweest (de andere verschillen worden verklaard door het verschil in inkomen per hoofd van de bevolking).

\section{Organisatie van de industrie - de rol van de Nederlandse Bioscoop Bond}

De Nederlandse bioscoopmarkt was om twee redenen in de jaren dertig afwijkend van de meeste Europese landen en de vs. Allereerst was het een open markt. Er waren geen quota of wetten noch onredelijk hoge importbelastingen om de buitenlandse producties buiten de deur te houden en de eigen filmindustrie te beschermen. ${ }^{28}$ Dit laatste zou overigens weinig zin hebben gehad daar er nauwelijks Nederlandse speelfilms geproduceerd werden. De Nederlandse markt werd gedomineerd door buitenlandse producties. Tussen 1934 en 1936 was 52 procent van de 24II titels die vertoond werden in de bioscopen uit de dataset afkomstig uit Hollywood; 27 procent uit Duitsland, 7 procent uit Frankrijk; 4 procent uit Groot-Brittannië en slechts 2 procent was van Nederlandse makelij. ${ }^{29}$

Ten tweede, de distributeurs - hoofdzakelijk Nederlandse, Duitse en Amerikaanse - en de (vooral Nederlandse) exploitanten waren lid van eenzelfde beroepsvereniging, namelijk de Nederlandse Bioscoop Bond (hierna NBB). $3^{\circ}$ De NBB was opgericht in I92I en had zich ontwikkeld tot een machtig kartel dat de prijzen en leveringsafspraken tussen distributeurs en vertoners nauwgezet controleerde. Een voorbeeld hiervan was de invoering van het standaardfilmverhuurcontract in $1924 .^{31}$ Het was leden verboden te handelen met niet-leden en bij overtreding van deze regel volgde een berisping of een boete, soms zelfs een boycot. ${ }^{32}$ In Groot-Brittannië en de Verenigde Staten was de industrie heel anders opgezet en hadden exploitan- 
ten eigen, strikt van de distributeurs en producenten gescheiden, organisaties opgericht. Dit leidde vaak tot heftige aanvaringen tussen kleine bioscoopketens en onafhankelijke vertoners, en de distributieafdelingen van de grote Hollywood- en/of Britse studio's. 33 De verticaal geïntegreerde studio's konden uiteraard ook zelf verwikkeld raken in een intern conflict tussen hun distributie- en hun vertoningsafdelingen.

Kartels functioneren als monopolies: ze veroorzaken hogere prijzen dan in een vrije markt zouden worden gehanteerd en beperken het aanbod. Volgens Karel Dibbets was de NBB dermate machtig op de Nederlandse markt dat zij in hoge mate verantwoordelijk gehouden kan worden voor het lage niveau van de filmconsumptie in Nederland. ${ }^{34}$ Zoals eerder gesteld bij de analyse van de data in tabel 4 hielden de Nederlandse bioscoopexploitanten tot I935 de toegangsprijzen hoog, ondanks de recessie. Deels lagen onderlinge prijsafspraken hieraan ten grondslag. Zo rapporteerden de Rotterdamse en Haagse afdelingen van de NBB in I93I dat ze erin geslaagd waren afspraken te maken over minimumprijzen voor de bioscoopkaartjes. ${ }^{35}$ In I932 verklaarde de NBB echter in reactie op deze lokale overeenkomsten dat er geen reden was voor algemene prijsafspraken op nationaal niveau daar vertoners niet in een prijzencompetitie waren geraakt en de prijzen niet zo gezakt waren als in het buitenland het geval was. Uit tabel 4 blijkt dat de gemiddelde toegangsprijs in I932 zelfs helemaal niet was gezakt en gelijk was aan die in I93I, namelijk 74 cent. ${ }^{6}$ Een jaar later verdedigde de NBB nogmaals het uitblijven van een algemene landelijke prijsverlaging, maar nu met het argument dat dit de markt slechts tijdelijk zou stimuleren. 37 Pas na I934 zette een echte prijsdaling in en in I936 zag het hoofdbestuur van de NBB zich toch genoodzaakt om in te stemmen met het opstellen van een minimumprijsregeling daar er chaos dreigde te ontstaan door de vele prijsverlagingen die de exploitanten op eigen houtje doorvoerden. De nieuwe regeling werd echter uitgesteld omdat de Nederlandse overheid de Gouden Standaard in datzelfde jaar verliet. ${ }^{8}$ Officieel heeft het hoofdbestuur van de NBB dus nooit direct ingegrepen in de prijsontwikkelingen op de bioscoopmarkt maar het liet wel oogluikend toe dat zijn leden - vooral de vertoners in de grote steden Amsterdam, Rotterdam en Den Haag - hun lokale markten reguleerden.

De terughoudendheid die het hoofdbestuur van de NBB betrachtte als het ging om prijsregulatie stond in schril contrast met de positie die het betrok zodra zijn leden bedreigd werden door mogelijke extra financiële lasten. Vanaf ı92i zijn de jaarverslagen gelardeerd met voorbeelden van protesten tegen hoge vermakelijkheidsbelastingen, personele belastingen, importbelastingen, hoge energierekeningen, auteursrechten voor de muziek die in de bioscopen gespeeld werd, enzovoort. Alle inspanningen waren gericht op het zo laag mogelijk houden van de exploitatiekosten. Een van hun breed uitgemeten successen was het voorkomen van een forse verhoging van de importbelasting op films in 1934.39

Gedurende de periode I930-I936 steeg het aantal bioscopen van 233 tot 333. Het grootste aantal nieuwkomers bestond uit kleine bioscopen. Deze expansie werd waarschijnlijk gestimuleerd door de hoge toegangsprijzen. Van de honderd nieuwe 
bioscopen waren er 65 met een capaciteit van minder dan vijfhonderd zitplaatsen. Slechts drie bioscopen hadden meer dan duizend zitplaatsen..$^{\circ}$ De uitbreiding van het Nederlandse bioscooppark met voornamelijk kleine zalen staat in scherp contrast met de situatie in Groot-Brittannië waar in dezelfde periode vooral grote bioscopen gebouwd werden. 'My own observation of the new building programme (...) leads to the conclusion that more than one half of the cinemas under construction are of the I,००० seater, or more, type' rapporteerde Rowson aan de Royal Statistical Society in $1935 .{ }^{\mathrm{AI}}$ Dus tijdens de lange recessie van de Nederlandse economie waarin, zoals we zagen in tabel 4 , de reële consumptieve uitgaven daalden, waren de prijzen van bioscoopkaartjes stabiel en bleven hoog, terwijl tegelijkertijd een aanzienlijk aantal nieuwe kleine bioscopen werd geopend. Het is dan ook begrijpelijk dat er een gevoel van crisis ontstond en de leden van de NBB begin 1935 besloten tot een tijdelijke afsluiting van de bedrijfstak voor nieuwe bioscopen tot het eind van dat jaar. $4^{2}$ Vanaf 1936 werd een vergunningsstelsel ingevoerd dat er volgens de NBB in zijn jaarverslag van 1939 toe had geleid dat slechts veertig nieuwe bioscopen waren geopend in plaats van de honderd waarmee het Nederlandse bioscooppark zonder deze beperkende maatregel ongetwijfeld was uitgebreid. ${ }^{43}$ Deze uitspraak is nooit te controleren en is waarschijnlijk een overdrijving maar illustreert wel het beleid van de NBB en het belang dat gehecht werd aan de beperking van het aantal bioscopen.

\section{Klasse als verklarende factor}

Zoals in de inleiding aangehaald, stellen Thissen en Van der Velden dat klasse betrokken zou moeten worden in het verklaren van de relatief kleine omvang van de Nederlandse bioscoopmarkt. Ze stellen dat 'de "echte", dat wil zeggen de niet alleen financieel-economisch, maar ook sociaal-cultureel gevestigde middenklasse' de bioscoop niet omarmd heeft. 44 Hun pleidooi om klasse serieus te nemen is een reactie op Dibbets, die veronderstelde dat er een beter ontwikkelde bioscoopsector had kunnen ontstaan als de zuilen zich meer hadden ontfermd over de bioscopen (in welk geval de bioscopen wellicht een groter (verzuild) publiek getrokken hadden). In het laatste deel van dit artikel willen we een begin maken met de analyse van de relatie tussen de omvang van het Nederlandse bioscooppark en de begrippen klasse en verzuiling.

De eerste vraag daarbij is hoe deze begrippen te operationaliseren. Thissen en Van der Velden spreken over 'de lagere sociale klassen en standen' en citeren het tijdschrift Het Centrum dat deze groep karakteriseert als 'de kleine en kleinere man ongeacht de inhoud van diens portemonnee'. 45 De definiëring van zowel de lagere als de middenklasse blijft echter achterwege en dient nader gespecificeerd te worden, zoals ook beide auteurs erkennen.

Historische gegevens die kunnen dienen als basis voor een economische definiëring van klasse zijn beperkt. Wel bekend is het aantal belastingbetalers dat naast 


\section{HET BIOSCOOPGEVAAR.}

(Ingediend is een Wetsontwerp tot bestrijding van het bioscoopgevaar.)

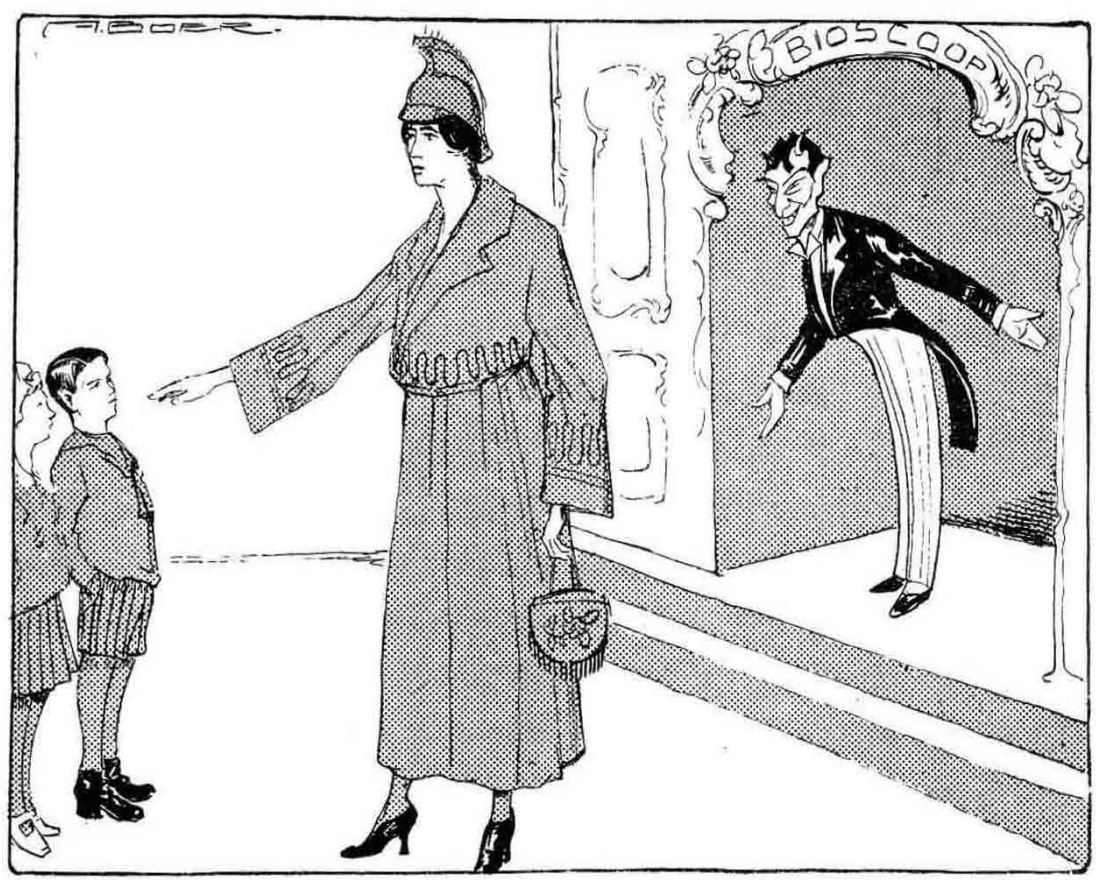

DE NEDERLANDSCHE MAAGD: „Halt!"

De Ster 23 sept. 1921.

Deze spotprent uit het protestants-christelijke blad De Ster toont de bioscoopexploitant verbeeld als duivel. Bron: A.S. de Gooyer, Het beeld der vad'ren. Een documentaire over het leven van het protestants-christelijke volksdeel in de twintiger en dertiger jaren, Utrecht 1964.

inkomstenbelasting in 1933 ook vermogensbelasting betaalde in $1934.4^{46}$ Deze variabele gebruiken we hier als eerste verkenning naar de relatie tussen klasse en het aanbod van bioscoopstoelen. De veronderstelling is dat als de bioscopen vooral bezocht werden door de lagere, minder vermogende klassen er dus meer bioscopen zouden moeten zijn in gebieden waar weinigen vermogensbelasting betaalden dan in gebieden waar veel inwoners vermogensbelasting betaalden.

Het tweede begrip, verzuiling en de invloed daarvan op de Nederlandse bioscoopsector in 1934-I936, werd eerder onderzocht door Boter en Pafort-Overduin. $\mathrm{Zij}$ constateerden geen groot effect van de verzuiling op de bioscoopprogrammering; er waren bijvoorbeeld geen films die alleen, of vooral, populair waren in domi- 
TABEL 5. Bevolking, bioscoopcapaciteit, en religie per plaats (gerangschikt naar aantal inwoners per stoel), 1934-1935

\begin{tabular}{|c|c|c|c|c|c|c|c|c|}
\hline Plaats & Inwoners & $\begin{array}{l}\text { Aantal } \\
\text { stoelen }\end{array}$ & $\begin{array}{l}\text { Inwo- } \\
\text { ners } \\
\text { per } \\
\text { stoel }\end{array}$ & $\begin{array}{l}\% \\
\text { Protestant } \\
\text { 1) }\end{array}$ & $\begin{array}{l}\% \\
\text { Katholiek } \\
\text { 2) }\end{array}$ & $\begin{array}{l}\% \\
\text { Socialistisch } \\
\text { 3) }\end{array}$ & $\begin{array}{l}\% \\
\text { Liberaal } \\
4)\end{array}$ & $\begin{array}{l}\% \text { Betalers } \\
\text { vermogens } \\
\text { belasting }\end{array}$ \\
\hline Apeldoorn & 68.590 & 77I & 89,0 & 42,2 & IO,I & 24,5 & 15,0 & $\mathrm{I} 4, \mathrm{O}$ \\
\hline Dordrecht & 60.13I & I.002 & 60,0 & $3 \mathrm{I}, 2$ & 9,2 & 37,3 & $\mathrm{I} 8, \mathrm{I}$ & 8,4 \\
\hline Groningen & II5.I 85 & 2.543 & 45,3 & 28,2 & 8,0 & 38,0 & 16,6 & 13,6 \\
\hline Haarlem & I31.257 & 3.203 & $4 \mathrm{I}, \mathrm{O}$ & $\mathrm{I} 7, \mathrm{I}$ & 26,7 & 35,3 & $\mathrm{I} 6,4$ & 9,8 \\
\hline Amsterdam & 78 г.645 & I9.559 & 40,0 & $\mathrm{I} 7, \mathrm{I}$ & I5,3 & 46,9 & I5, 2 & 6,3 \\
\hline Schiedam & 6г.845 & I.6I4 & 38,3 & 28,3 & 25,3 & 30,4 & 9,9 & 5,4 \\
\hline Heerlen & $49 \cdot 724$ & I. 407 & 35,3 & 6,8 & 60,4 & 20,0 & $\mathrm{I}, 8$ & 5,3 \\
\hline Utrecht & I6I.093 & 4.589 & $35, \mathrm{I}$ & 24,5 & 27,3 & $3 \mathrm{I}, 3$ & $\mathrm{I} 3, \mathrm{I}$ & $9, \mathrm{I}$ \\
\hline Rotterdam & 595.448 & I7.IOO & 34,8 & 23,7 & 15,6 & 40,7 & $\mathrm{I} 3,4$ & 6,6 \\
\hline Leiden & 73.6I2 & 2.199 & 33,5 & $3 \mathrm{I}, 8$ & 20,9 & 33,0 & IO, 4 & 9,2 \\
\hline Tilburg & 88.890 & 2.990 & 29,7 & 2,7 & 80,6 & II,O & $\mathrm{I}, 4$ & 8,7 \\
\hline Zeist & 29.69 I & 1.050 & 28,3 & 44,5 & $\mathrm{I} 2,3$ & 20,5 & $\mathrm{I} 7,6$ & I 8,8 \\
\hline Den Haag & 482.397 & $\mathrm{I} 7.740$ & 27,2 & 24,8 & $\mathrm{I} 8,2$ & 32,7 & 16,5 & $\mathrm{I} 3, \mathrm{O}$ \\
\hline Eindhoven & 103.030 & 3.808 & $27, I$ & 6,5 & $68, \mathrm{I}$ & I 8,4 & 3,5 & 6,3 \\
\hline Maastricht & 65.929 & 2.450 & 26,9 & 2,2 & 60,4 & 27,5 & 2,2 & 8,9 \\
\hline Nijmegen & 90.739 & 4.365 & 20,8 & 8,6 & 62,8 & I 8,7 & 6,3 & $\mathrm{I} 4,3$ \\
\hline Culemborg & $9 \cdot 359$ & 500 & I 8,7 & I5,I & 39,0 & 28,5 & 15,2 & $\mathrm{I} 4, \mathrm{O}$ \\
\hline Geleen & $\mathrm{I} 4.289$ & 900 & 15,9 & 5,4 & 66,8 & $\mathrm{I}_{4}, 8$ & 0,7 & 4,8 \\
\hline Zierikzee & 6.944 & 450 & 15,4 & 37,0 & $\mathrm{I} 2,4$ & $20, \mathrm{I}$ & 26,8 & $2 \mathrm{I}, 8$ \\
\hline 's-Hertogenbosch & $46.2 \mathrm{I} 2$ & 3.098 & I4,9 & 4,2 & 68,7 & IO,7 & 2,6 & 8,3 \\
\hline Alkmaar & 30.467 & 2.566 & $\mathrm{II}, 9$ & I2, 8 & $3 \mathrm{I}, 5$ & $3 \mathrm{I}, 2$ & $2 \mathrm{I}, \mathrm{I}$ & $\mathrm{I} 4,3$ \\
\hline Tiel & $\mathrm{I} 2.730$ & I.I38 & $\mathrm{II}, 2$ & $\mathrm{I} 4,3$ & $2 \mathrm{I}, 9$ & 37,6 & I9,I & $\mathrm{I} 2,8$ \\
\hline
\end{tabular}

Bronnen: Cinema Context Collection; Beekink, Boonstra, Engelen \& Knippenberg (red.), Nederland in verandering: maatschappelijke ontwikkelingen in kaart gebracht, 1800-2000 (2003).

I. ARP, CHU, SGP, CDU en Hervormd Gereformeerde Partij.

2. Rooms-Katholieke Staatspartij en Rooms-Katholieke Volkspartij.

3. SDAP, CPH en Revolutionair-Socialistische Partij.

4. Vrijzinnig Democratische Bond en Vrijheidsbond.

nant katholieke gebieden. Qua aantal bioscoopstoelen was er echter een duidelijk 'protestants effect' te onderscheiden. Meest opvallend is bijvoorbeeld Apeldoorn; hier was het laagste aantal bioscoopstoelen beschikbaar per hoofd van de bevolking. Dit kon dus niet worden verklaard uit de bevolkingsomvang; alleen door het grote aantal protestanten in die gemeente. Boter en Pafort-Overduin veronderstelden dat protestanten een remmende werking hadden op de capaciteit van bioscopen. 47 
In tabel 5 wordt per plaats vermeld wat de bevolkingsomvang is (kolom I), het totaal aantal beschikbare bioscoopstoelen en het aantal inwoners per stoel (kolom 2 en 3). Daarnaast is het aantal stemmen opgenomen dat is uitgebracht op de verschillende zuilen voor de provinciale verkiezingen van I935 en het percentage van de bevolking dat vermogensbelasting betaalde. De plaatsen zijn aflopend gesorteerd op aantal inwoners per bioscoopstoel. Daarnaast hebben we ook het percentage inwoners dat vermogensbelasting betaalde in I934 opgenomen als indicator voor lokale verschillen in welvaart.

Opvallend is dat in geval van een hoog aantal personen per bioscoopstoel (dus hoe kleiner het aanbod van bioscoopstoelen) vaker het aandeel protestantse stemmen hoog was. Het protestants effect lijkt zich dus te herhalen, zij het niet overal even sterk. Het tegenovergestelde effect is zichtbaar bij de vermogensbelastingbetalers: de bovenste helft van de kolom heeft vaker een laag percentage vermogensbelastingbetalers dan de onderste helft van de kolom. Deze resultaten lijken te duiden op een negatieve samenhang tussen het aantal inwoners per bioscoopstoel en het aantal vermogensbelastingbetalers; hoe hoger het percentage vermogensbelastingbetalers hoe groter het aanbod van bioscoopstoelen.

Met behulp van een (stepwise) lineaire regressie hebben we onderzocht of het betalen van vermogensbelasting en omvang (van een) van de kiezersgroepen behorende tot een van de vier zuilen een statistisch significante verklaring geeft voor het aantal aanwezige bioscoopstoelen in een bepaalde plaats. ${ }^{4}$ Dit resulteert in het volgende model (Adj. $\left.\mathrm{R}^{2}=.407, p<.0 \mathrm{I}\right)$ :

TABEL 6. (Stepwise) lineaire regressie aantal inwoners per bioscoopstoel

\begin{tabular}{lllll}
\hline & $B$ & Std. Error & Standardized beta & $t$ \\
\hline Constante & 32,849 & 7,604 & & 4,320 \\
\% stemmers op protestantse partijen & $\mathrm{I}, 056$ &, 265 &, $779 * * *$ & 3,986 \\
\% betalers vermogensbelasting & $-2,035$ &, 762 &,$- 522^{*}$ & $-2,670$ \\
\hline
\end{tabular}

$* p<.05$

$* * x<.01$

Uit de regressieanalyse blijkt dat economische welstand, uitgedrukt in het percentage inwoners dat vermogensbelasting betaalde, de capaciteit van de bioscopen beïnvloedt: hoe hoger dit percentage hoe meer bioscoopstoelen. Sterker is het protestants effect (uitgedrukt in stemmers op protestantse partijen): dit correleert positief met het aantal inwoners per bioscoopstoel en heeft dus een negatieve invloed op de bioscoopcapaciteit.

De vraag is of dit effect veroorzaakt wordt door de aanwezigheid van protestanten die niet naar de bioscoop gingen zodat de omvang van de lokale bioscoopmarkt kromp. Of van een top-down-effect waardoor bioscoopeigenaren werden beperkt in 
TABEL 7. Bioscoopbezetting, bioscoopstoelen, inwoners, religie en vermogensbelasting (gerangschikt naar vertoningen per stoel)

\begin{tabular}{|c|c|c|c|c|c|c|c|}
\hline Plaats & $\begin{array}{l}\text { Totaal } \\
\text { aantal } \\
\text { vertoningen }\end{array}$ & $\begin{array}{l}\text { Totaal } \\
\text { aantal } \\
\text { stoelen }\end{array}$ & $\begin{array}{l}\text { Vertoningen } \\
\text { per } \\
\text { stoel }\end{array}$ & Inwoners & $\begin{array}{l}\text { Inwoners } \\
\text { per } \\
\text { stoel }\end{array}$ & $\begin{array}{l}\% \\
\text { Protestant } \\
\text { 1) }\end{array}$ & $\begin{array}{l}\% \text { Vermogens- } \\
\text { belasting } \\
\text { betalers }\end{array}$ \\
\hline Utrecht & I9. 868,3 & 4.589 & 4,3 & I61.093 & $35, \mathrm{I}$ & 24,5 & $9, \mathrm{I}$ \\
\hline Haarlem & $13.037,4$ & 3.203 & $4, \mathrm{I}$ & I3I.257 & $4 \mathrm{I}, \mathrm{O}$ & $\mathrm{I} 7, \mathrm{I}$ & 9,8 \\
\hline Amsterdam & $72.673, \mathrm{I}$ & I9.559 & 3,7 & 781.645 & 40,0 & $\mathrm{I} 7, \mathrm{I}$ & 6,3 \\
\hline Rotterdam & $58.218,9$ & I7.100 & 3,4 & 595.448 & 34,8 & 23,7 & 6,6 \\
\hline Den Haag & $48.34 \mathrm{I}, 8$ & $\mathrm{I} 7.740$ & 2,7 & 482.397 & 27,2 & 24,8 & 13,0 \\
\hline Groningen & $6.809,3$ & 2.543 & 2,7 & II5.I85 & 45,3 & 28,2 & I3, 6 \\
\hline Apeldoorn & I.900,6 & 77I & 2,5 & 68.590 & 89,0 & $4^{2,2}$ & $\mathrm{I} 4, \mathrm{O}$ \\
\hline Tilburg & $6.024,7$ & 2.990 & 2,0 & 88.890 & 29,7 & 2,7 & 8,7 \\
\hline Dordrecht & $2.009,4$ & I.002 & 2,0 & 60.13I & 60,0 & $3 \mathrm{I}, 2$ & 8,4 \\
\hline Zeist & I.9I2,4 & I.050 & I, 8 & $29.69 \mathrm{I}$ & 28,3 & 44,5 & I 8,8 \\
\hline Eindhoven & $6.68_{3, \mathrm{I}}$ & 3.808 & $\mathrm{I}, 8$ & 103.030 & $27, \mathrm{I}$ & 6,5 & 6,3 \\
\hline Maastricht & 4.129, 5 & 2.450 & $\mathrm{I}, 7$ & 65.929 & 26,9 & 2,2 & 8,9 \\
\hline Nijmegen & $7.228,5$ & 4.365 & $\mathrm{I}, 7$ & 90.739 & 20,8 & 8,6 & I 4,3 \\
\hline Alkmaar & $4.137,0$ & 2.566 & $\mathrm{I}, 6$ & 30.467 & II,9 & I 2,8 & $\mathrm{I} 4,3$ \\
\hline Schiedam & $2.455,8$ & I.6I4 & $\mathrm{I}, 5$ & 6I. 845 & 38,3 & 28,3 & 5,4 \\
\hline Leiden & $2.862,9$ & 2.199 & $\mathrm{I}, 3$ & $73.6 \mathrm{I2}$ & 33,5 & $3 \mathrm{I}, 8$ & 9,2 \\
\hline Geleen & I.I 37,2 & 900 & $\mathrm{I}, 3$ & I4.289 & I5,9 & 5,4 & 4,8 \\
\hline Heerlen & I. 729,5 & I.4O7 & $\mathrm{I}, 2$ & 49.724 & 35,3 & 6,8 & 5,3 \\
\hline Tiel & 953,4 & I.I38 & 0,8 & $\mathrm{I} 2.730$ & $\mathrm{II}, 2$ & $\mathrm{I} 4,3$ & I2, 8 \\
\hline Den Bosch & $2.59 \mathrm{I}, 4$ & 3.098 & 0,8 & 46.212 & 14,9 & 4,2 & 8,3 \\
\hline Culemborg & 300,1 & 500 & 0,6 & 9.359 & I 8,7 & I5,I & $\mathrm{I}_{4}, \mathrm{O}$ \\
\hline Zierikzee & $\mathrm{I} 64,7$ & 450 & 0,4 & 6.944 & 15.4 & 37,0 & $2 \mathrm{I}, 8$ \\
\hline
\end{tabular}

Bronnen: Cinema Context Collection; Beekink, Boonstra, Engelen \& Knippenberg (red.), Nederland in verandering: maatschappelijke ontwikkelingen in kaart gebracht, 1800-2000 (2003).

I. ARP, CHU, SGP, CDU en Hervormd Gereformeerde Partij.

door protestanten gedomineerde gebieden door bijvoorbeeld lokale regelgeving of politieke relaties. Daar de bioscopen vaste activa vormden, mogen we aannemen dat exploitanten bij een gestegen vraag het aantal vertoningen verhoogden waardoor er dus meer vertoningen per bioscoopstoel geteld zouden moeten worden.

Tabel 7 laat zien dat er wat betreft het aantal vertoningen per stoel (kolom 4) inderdaad een grote variatie is in de intensiteit waarmee het aantal stoelen werd gebruikt; in sommige steden hadden de bioscoopstoelen een hogere kaartverkooppotentie omdat er relatief gezien meer vertoningen werden gegeven. Een stapsgewijze lineaire regressie van voorstellingen per stoel, zoals ook uitgevoerd in tabel 6 , laat echter zien dat noch het aantal inwoners per bioscoopstoel, noch het percentage 
stemmers op protestantse partijen een significant effect hebben en de verschillen in de intensiteit van de programmering kunnen verklaren (Adj. $\mathrm{R}^{2}=.6 \mathrm{I}$, $p<. \mathrm{OI}$ ). Slechts (de log van) de bevolkingsomvang heeft een significant effect op de intensiteit waarmee de stoelen gebruikt worden $(\beta=.77 \mathrm{I}, p<. \mathrm{OI})$.

Met andere woorden: vanwege het gebrek aan extra vertoningen (om aan de vraag te voldoen), lijken de verschillen in de variatie in het aantal inwoners per bioscoopstoel verklaard te moeten worden als een effect van de vraag (het gebrek daaraan) waarbij het percentage protestanten al naar gelang zijn omvang de bioscoopmarkt lijkt te verkleinen. De protestantse partijen behaalden 25,7 procent van de uitgebrachte stemmen bij de algemene verkiezingen van I933. De reële omvang van de Nederlandse markt zou wellicht met een vergelijkbaar percentage moeten worden verminderd. 49

\section{Conclusie}

Hoe luidt nu op basis van de hier uitgevoerde analyse en vergelijking het antwoord op de vraag hoe we de achtergebleven ontwikkeling van de Nederlandse bioscoopsector kunnen verklaren? Er lijken drie oorzaken aan te wijzen die elk een rol hebben gespeeld. De belangrijkste hiervan is ons inziens de prijs van het Nederlandse bioscoopkaartje dat in vergelijking met Groot-Brittannië hoog was. Uit de vergelijking bleek dat Nederlanders eenzelfde percentage van hun consumptiebudget aan bioscoopbezoeken besteedden maar dat ze voor dit bedrag simpelweg minder kaartjes konden kopen. Op basis van deze gegevens lijkt er geen sprake te zijn geweest van een verminderde vraag naar bioscoopvertier maar van een beperkt aanbod waardoor de prijzen hoog bleven. De hoge prijzen maakten het mogelijk dat er relatief kleine theaters gebouwd werden. De sector zelf, onder leiding van de NBB, was dus in belangrijke mate verantwoordelijk voor de achtergebleven ontwikkeling.

Deze verklaring blijkt echter vooral van toepassing in de drie grote steden. Elders in het land speelden ander factoren ook een rol. Het zogenaamde 'protestantse effect' laat zien dat de mijdende houding die protestanten ten aanzien van film en bioscoopbezoek hadden, leidde tot het nog verder achterblijven van de bioscoopsector. Een derde - minder sterk - effect was dat van klasse, geoperationaliseerd door het aantal Nederlanders dat vermogensbelasting betaalde. In tegenstelling tot wat Thissen en Van der Velden opperden voor Rotterdam tot eind jaren twintig, lijkt in de periode I934-I936 de aanwezigheid van meervermogende burgers een positief effect te hebben op de aanwezigheid van bioscopen. Dit kan betekenen dat of Rotterdam niet representatief is voor de rest van Nederland, of dat vanaf eind jaren twintig tot halverwege de jaren dertig - de periode dat de geluidsfilm zijn intrede deed! film beter geïntegreerd raakte in Nederland. Maar ook de vraag of er gemeten wordt wat we willen meten, moet worden gesteld. Is er bijvoorbeeld een samenhang tussen de aanwezigheid van meervermogenden en die van socialisten, met andere 
woorden duidt de aanwezigheid van vermogensbelastingbetalers op de aanwezigheid van veel arbeiders die voor hen werkten? Daarvoor zou het begrip vermogensbelasting verder uitgesplitst moeten worden. Het is immers mogelijk dat in gebieden met een laag percentage vermogensbelastingbetalers juist de topinkomens met een hoge 'werkverschaffende capaciteit' goed vertegenwoordigd waren. Een analyse van inkomen en inkomensverdeling is gezien de resultaten een voor de hand liggende volgende stap in de verklaring van de verspreiding van bioscopen.

Hoewel de uitkomsten van onze analyses een nieuw licht werpen op de achterblijvende ontwikkeling van de Nederlandse bioscoopsector blijven er voldoende vragen over. Vanaf welk moment ging het percentage van de consumptieve bestedingen aan bioscoopbezoek in Nederland gelijke tred houden met dat in Groot-Brittannië? En hoe verhouden deze cijfers zich tot andere landen met een beter ontwikkelde bioscoopsector zoals Duitsland of Frankrijk? En wat gebeurde er met de prijzen van de bioscoopkaartjes en het bioscoopbezoek nadat in 1936 de Gouden Standaard werd losgelaten? Was dit een stimulans voor de sector of kregen bioscoophouders juist meer moeite het hoofd boven water te houden wegens dalende prijzen en een gelijkblijvende zaalcapaciteit?

Voorlopig kunnen we echter constateren dat in de periode I934-I936 (macro-)economische factoren de belangrijkste reden lijken te zijn voor de achterblijvende ontwikkeling van de Nederlandse bioscoopsector.

\section{Noten}

I Film Daily Yearbook (I938), p. I244; S. Rowson, 'A Statistical Survey of the Cinema Industry in Great Britain in I934', in: Journal of the Royal Statistical Society, 99, I936, p. 67-I29, tabel X. In andere naburige Europese landen was de ratio per bioscoopstoel: I op I8 in Zweden, I op 20 in Frankrijk, I op 33 in Zwitserland, I op 39 in Duitsland, I op 39 in Denemarken, I op 40 in Noorwegen. Kine Weekly, 26 August 1937 .

2 K. Dibbets, 'Het bioscoopbedrijf tussen twee wereldoorlogen', in: K. Dibbets \& F. van der Maden (red.), Geschiedenis van de Nederlandse film en bioscoop tot 1940, Houten I986, p. 229-270; K. Dibbets, 'Het taboe van de Nederlandse filmcultuur: Neutraal in een verzuild land', in: Tijdschrift voor Mediageschiedenis (verder TMG), jg. 9, nr. 2, 2006, p. 46-64; J. Thissen \& A. van der Velden, 'Klasse als factor in de Nederlandse filmgeschiedenis. Een eerste verkenning', in: TMG, jg. I2, nr. I, 2009, p. 50-72.

4

5

6 Thissen \& Van der Velden, 'Klasse als factor in de Nederlandse filmgeschiedenis', p. 50.

7 Ibidem, p. 54-55. De auteurs spreken over II theaters. Van het elfde theater is onduidelijk of de capaciteit 700 of 900 zitplaatsen was. Daarom laten we dit hier buiten beschouwing.

8 Ibidem, p. 54 .

9 W. Greenwald, 'The Motion Picture Industry: an Economic Study of the History and Practices of a Business', PhD thesis, New York University, I950.

Io M. Pokorny \& J. Sedgwick, 'Profitability trends in Hollywood: I929 to I999', in: Economic History Review, 63, 2010, p. 56-84. Een normale verdeling zou een zogenaamde klokvorm hebben: veel punten rond het gemiddelde en weinig punten aan de uitersten. In een long tail is de verdeling scheef; in dit 
geval dus weinig films die grote winsten maken en veel films die niet of nauwelijks winst maken. Deze laatste groep vormt de long tail.

II Het distributiemechanisme dat we beschreven ontstond in I9I4 met de vestiging van Paramount. Rond I9I8 had Paramount contracten met veel grote producenten. In I9I6 was het samengegaan met Famous Players en had zo controle gekregen over een flink aantal grote sterren. Op die manier kon Paramount zijn product differentiëren en tegemoetkomen aan de snel groeiende vraag naar films. Doordat Paramount het exclusieve recht had op de output (de films) van een fors aantal studio's kon het op veel plaatsen in de vs een block booking-systeem invoeren; in I9I8 leverde Paramount maar liefst 220 films in de vs. In de vs was dus het dominante distributiesysteem volgroeid in I9I8. Gezien het belang van de Britse markt en de aanwezigheid van Amerikaanse distributeurs in Londen is het aannemelijk dat de Britse markt - wellicht twee jaar later - op dezelfde wijze georganiseerd was. Zie ook: J. Izod, Hollywood and the box-office, London I988, p. 45-52. De analyses van Bolton en Brighton zijn afkomstig uit: J. Sedgwick, Popular Filmgoing in 1930 B Britain. A Choice of Pleasures, Exeter 2000, hoofdstukken 5 en 6. De analyse van Portsmouth komt uit J. Sedgwick, 'Cinemagoing in Portsmouth during the I930s', in: Cinema Journal, 46, 2006, p. 52-85.

I2 In een prijsdiscriminatiemodel wordt gestreefd naar winstmaximalisatie door verschillende prijzen aan verschillende consumenten te rekenen. Een kaartje voor de première is duurder dan een kaartje voor een vertoning in een kleine bioscoop ergens aan het eind van de distributiecyclus.

I3 We kunnen aannemen dat het maken van winst het belangrijkste doel is voor kapitalistische organisaties. De vraag is hoe de winsten het beste gemaximaliseerd kunnen worden. In een normaal model gaat de winst van de een altijd ten koste gaat van de ander. (Als de distributeur veel vraagt kan de vertoner minder verdienen en andersom.) Bij de NBB werd er duidelijk niet van winstmaximalisatie uitgegaan en moesten beide partijen tot een vergelijk komen. Het is een mythe dat verticaal geïntegreerde organisaties alleen zelfgeproduceerde films leverden. Distributeurs trachtten hun films bij zo veel mogelijk vertoners af te zetten - inclusief de bioscopen die tot de verticaal geïntegreerde ketens behoorden - tegen een afgesproken prijs (een bepaald deel van de brutokaartverkoop). Hoe prestigieuzer een film, hoe hoger het huurpercentage. United Artists was alleen een distributeur. In plaats van een verticaal geïntegreerde organisatie had het zowel contacten met grote producers zoals Goldwyn in de vs en London Films in Groot-Brittannië als met bioscopen waaronder een aantal 'showcase'-bioscopen. Zie ook: F. Hanssen, 'The block booking of films re-examined', in: Journal of Law and Economics, 43, 2000, p. 395-426; F. Hanssen, 'Revenue-sharing in movie exhibition and the arrival of sound', in: Economic Inquiry, 40, 2002, p. 380-402; beide te vinden in J. Sedgwick, M. Pokorny (eds), An Economic History of Film, London 2005. I4 In Bolton kostte een kaartje voor een first run-bioscoop 6 of 7 cent, de meeste andere bioscopen rekenden 4 cent. (Er gingen 240 cent in een Engels Pond. Zie Sedgwick, Popular Filmgoing, Table 5.I.). Browning en Sorrell (1954) schatten de gemiddelde prijs van een bioscoopkaartje in Groot-Brittannië op iets meer dan Io cent. Zie Sedgwick, Popular Filmgoing, Table 2.I. De grote premièretheaters op London West End rekenden aanzienlijk meer, een middelduur kaartje kostte meer dan 4 shilling (48 cent). De film LIVES OF A BENGAL LANCER (met Gary Cooper) opende bijvoorbeeld begin februari I935 in de Carlton bioscoop op Londons West End (IIо० zitplaatsen) en draaide daar negen weken. De toegangsprijzen varieerden tussen de 28 cent en 126 cent. Begin augustus I 935 was de film te zien in twee theaters in Bolton: Hippodrome (I086 zitplaatsen) en Capital (I642 zitplaatsen). De toegangsprijzen varieerden respectievelijk tussen de 6 cent en i 6 cent, en tussen de 7 cent en I 8 cent. In totaal werd de film vertoond in acht verschillende bioscopen in Bolton met als afsluiting een driedaagse boeking als single bill in de week van 20 januari 1936 in Royal ( 76 I zitplaatsen) en Belle (580 zitplaatsen). De toegangsprijzen van deze bioscopen liepen respectievelijk van 5 cent tot I2 cent, en van 4 cent tot 9 cent.

I5 Alkmaar, Apeldoorn, Culemborg, Dordrecht, Eindhoven, Haarlem, 's-Hertogenbosch, Leiden, Nijmegen, Schiedam, Tiel, Tilburg, Utrecht en Zeist.

I6 Deze data werden verzameld voor het proefschrift van C. Pafort-Overduin dat nog niet gepubliceerd is. Centraal Bureau voor de Statistiek, Statistiek van het bioscoopwezen 1937, 's-Gravenhage, I938.

I7 De Cinema Context Collection is een digitale collectie toegankelijk via internet waarin data zijn opgenomen over bioscoopcultuur in Nederland. Het bevat informatie over bioscopen, filmprogramma's en censuur: www.cinemacontext.nl. 
I8 De meerderheid van de vertoonde films bestond uit speelfilms. Een enkele keer is een documentaire opgenomen in de dataset als deze op dezelfde manier geprogrammeerd werd als een lange speelfilm in het hoofdprogramma. Dit was bijvoorbeeld het geval met 20.000 MIJLEN ONDER ZEE, een lange Polygoondocumentaire over de reis rond de wereld van de Nederlandse onderzeeër K XVIII. Normaal gesproken werden documentaires vertoond als onderdeel van het voorprogramma of op zondagochtenden tijdens de zogenaamde 'wetenschappelijke vertoningen'.

I9 Tabel 3 bevat de cijfers van de films die geboekt zijn over een periode van drie jaar, terwijl de cijfers in tabel I een periode van twee jaar (I934-I935) beslaan als het gaat om Bolton en Brighton, en één jaar (I934) in het geval van Portsmouth.

20 Zie voor een uitleg van het voortschrijdend gemiddelde: http://www.let.leidenuniv.nl/history/RES/ stat/html/les3.html\#hetv.

2I Deze films waren afkomstig uit verschillende jaren en werden gedistribueerd door kleine distributeurs naar vaak kleine plaatsen.

22 Rowson, 'Statistical Survey of the Cinema'. Deze cijfers zijn afgeleid uit de Entertainment Tax returns.

23 H. Browning \& A. Sorrell, 'Cinema and cinema-going in Great Britain', in: Journal of the Royal Statistical Society, II7, I954, p. I33-165.

24 Film Daily Yearbook of Motion Pictures, I938, p. I244; Statistiek van het bioscoopwezen 1937, p. I2-I3 en tabel I3; Dibbets, 'Het bioscoopbedrijf tussen twee wereldoorlogen', tabel I.

25 C. Feinstein, P. Temin \& G. Toniolo, The European economy between the wars, Oxford I997, tabel 9.3.

26 De statistieken voor de Britse consumptieve uitgaven komen uit S. Solomou \& M. Weale, 'UK national income, 1920-38: the implications of balanced estimates', in: Economic History Review, 49, 1996, p. I05-II5, table Ar. De bron voor de Nederlandse consumptieve statistieken is G. den Bakker, Th. Huitker \& C. van Bochove, 'The Dutch Economy I92I-39: Revised Macroeconomic Data for the Interwar Period', in: Review of Income and Wealth, 36, I990, p. I87-206, tabel AI. De werkeloosheid begon op een veel lager niveau in Nederland waar 2,3 procent van de beroepsbevolking in I930 werkeloos was terwijl in Groot-Brittannië I2,5 procent werkeloos was in 1930 wat opliep tot I7 procent in I932. C. Feinstein, Statistical tables of national income, expenditure and output of the United Kingdom 1855-1965. Cambridge 1972, tabel 58. Nederlandse prijzen daalden veel meer tijdens de depressie dan de Britse prijzen, maar op een later moment. Als beide prijsreeksen op Ioo worden gesteld voor 1930, daalden de Britse prijzen al naar een dieptepunt op 88,4 in 1933, terwijl het Nederlandse prijsniveau pas in 1936 daalde tot (het lagere) $8 \mathrm{I}, 4$.

27 De wisselkoers is overgenomen uit Statistical Yearbook of the League of Nations, 1936, Table I, p. I2. Nederland liet de Gouden Standaard pas los in september 1936. J.L. van Zanden, The economic history of the Netherlands: a small open economy in the 'long' twentieth century, London I998, p. IIO.

28 De Amerikanen rapporteren 'taxation is not considered excessive', in: Film Daily Yearbook of 1938 , p. I243.

29 Dit komt goed overeen met een overzicht dat werd gepubliceerd in het jaarboek van 1938 van het handelsblad Film Daily waarin werd aangeven uit welke landen de films die in Nederland werden vertoond afkomstig waren. Zij melden als de verhoudingen voor I935: 55 procent Vs, I8 procent Duitsland, 8,7 procent Frankrijk, 4,6 procent Tsjecho-Slowakije, 4,9 procent voor Oostenrijk en 5,2 procent voor het Verenigd Koninkrijk. Film Daily Yearbook of 1938, p. I243-44.

30 Filmstudio's en filmlaboratoria konden lid worden vanaf 1932, en filmproducenten in 1937. Dibbets, 'Het bioscoopbedrijf tussen twee wereldoorlogen', p. 249.

3I Jaarverslag van de Nederlandse Bioscoop Bond 1924, p. 9. Reeds in I92I werd een standaardcontract opgesteld, maar dit was erg basaal. Jaarverslag van de Nederlandse Bioscoop Bond 1921, p. I2-I3.

32 Jaarverslag van de Nederlandse Bioscoop Bond 1921, p. I8; Jaarverslag van de Nederlandse Bioscoop Bond 1922, p. 28; Jaarverslag van de Nederlandse Bioscoop Bond 1927, p. 3I. In het jaarverslag van 1927 werd gemeld dat aan het eind van dat jaar waarschijnlijk alle ondernemers lid waren van de NBB. Jaarverslag van de Nederlandse Bioscoop Bond 1927, p. 36.

33 Zie 'Hearing before a Subcommittee of the Committee on Interstate and Foreign Commerce, House of Representatives, Seventy Fourth Congress, on Bill to Prohibit and to Prevent the Trade Practices 
Known as "Compulsory Block-Booking" and "Blind Selling", in: The Leasing of Motion Picture Films in Interstate and Foreign Commerce, Washington DC 1936.

34 Dibbets, 'Taboe van de Nederlandse filmcultuur', p. 6o-6r.

35 Jaarverslag van de Nederlandse Bioscoop Bond 1931, p. 78 en p. 8I.

36 Jaarverslag van de Nederlandse Bioscoop Bond 1932, p. 80.

37 Jaarverslag van de Nederlandse Bioscoop Bond 1933, p. 7I.

38 Jaarverslag van de Nederlandse Bioscoop Bond 1936, p. 22-24.

39 Jaarverslag van de Nederlandse Bioscoop Bond 1934, p. 4-6.

40 Statistiek van het bioscoopwezen 1937, tabel 3.

4I Rowson, 'Cinema industry', p. 79. In tabel V meldt Rowson dat eind I934 net iets minder dan 50 procent van de bestaande 4305 bioscopen een capaciteit van meer dan Ioo० zitplaatsen had.

42 Jaarverslag van de Nederlandse Bioscoop Bond 1934, p. 15-20. Er waren vier uitzonderingen: I) in plaatsen zonder bioscoop; 2) als de investeringen voor de nieuw te openen bioscoop gedaan waren voor februari I935; 3) distributeurs die failliet waren gegaan; 4) filmproductiebedrijven.

43 Jaarverslag van de Nederlandse Bioscoop Bond 1936, p. II-I3; Jaarverslag van de Nederlandse Bioscoop Bond 1939, pp. I8-I9. Zie ook Dibbets \& Van der Maden, Geschiedenis van de Nederlandse film, p. 29 I.

44 Thissen \& Van der Velden, 'Klasse als factor in de Nederlandse filmgeschiedenis', p. 6r.

45 Ibidem.

46 E. Beekink, O. Boonstra, Th. Engelen \& H.Knippenberg (red.), Nederland in verandering: maatschappelijke ontwikkelingen in kaart gebracht, 1800-2000, Amsterdam 2003, tabel Vermogensbelasting betaald in I934. Er werd vermogensbelasting betaald over vermogens vanaf I6.000 gulden. N. Wilterdink, Vermogensverhoudingen in Nederland. Ontwikkelingen sinds de negentiende eeuw, Amsterdam I984, p. IIo, tabel 4. Zie voor de publicatie online: http://www.dbnl.org/tekst/wiltoorvermoI_oI/colofon.htm. I6.ooo gulden staat gelijk aan een kleine I32.000 euro in 20 I0.

47 J. Boter \& C. Pafort-Overduin, 'Compartmentalisation and its Influence on Film Distribution and Exhibition in the Netherlands, I934-I936', in: M. Ross, M. Grauer \& B. Freisleben (eds.), Digital Tools in Media Studies. Analysis and Research. An Overview, Media Upheavels, vol 27, Bielefeld 2009. Er is geen onderscheid gemaakt tussen de verschillende stromingen binnen het protestantisme daar in alle gevallen fictiefilm werd afgewezen en de houding van alle protestanten als 'mijdend' kan worden gekarakteriseerd. Zie voor de houding van protestanten en katholieken ten opzichte van film: J. Hes, In de ban van het beeld, Assen i992.

48 Zie voor een uitleg van de gebruikte analysetechniek: http://www.let.leidenuniv.nl/history/RES/ VStat/html/les6.html\#_I_5.

49 Beekink et al., Nederland in verandering, melden dat de ARP, CHU, SGP en Hervormd Gereformeerde Partij gezamenlijk 957.8I2 stemmen trokken van de 3.72I.828 stemgerechtigden bij de algemene verkiezingen van I933. 